\title{
Factors explaining the level of voluntary human capital disclosure in the Brazilian capital market
}

\author{
Fernando Batista Fontana, Clea Beatriz Macagnan \\ Universidade do Vale do Rio dos Sinos (UNISINOS) (Brazil) \\ fbfontana@unisinos.br,clea@unisinos.br
}

Received: December 2011

Accepted: December 2012

\begin{abstract}
Purpose: This paper presents a study on factors explaining the level of voluntary human capital information in companies with shares in the Brazilian stock exchange. Assuming the existence of information asymmetry between managers and shareholders, agency theory states that disclosure might lead to a reduction in agency costs. The proprietary costs theory indicates that information disclosure might increase the company's costs. According to these theories, the likelihood that the managers will voluntarily disclose information depends on certain factors that are characteristic of the company. Understanding the disclosure of information regarding intangible assets, specifically human capital, has strategic relevance for enterprises because these features, although not always recorded in accounting, represent a competitive business edge in the current economy.
\end{abstract}

Design/methodology/approach: The study examined 145 annual reports, representing 29 companies in the period of 2005-2009. The level of voluntary disclosure was determined through content analysis of annual reports using representative indicators of human capital information.

Findings: The statistical results indicate that factors such as size, debt, growth and time of registration with the Brazilian Securities and Exchange Commission explain the level of voluntary human capital disclosure of the companies studied.

Originality/value: An important contribution of this research is the formulation and non-repudiation of the time of registration with the CVM hypothesis as a factor that 
explains the level of human capital disclosure because none of the revised studies have tested this hypothesis.

Keywords: Information asymmetry, voluntary disclosure, human capital, agency theory, proprietary costs theory

JEL Codes: D80

\section{Introduction}

This article presents a study of the factors explaining the level of voluntary human capital disclosure in companies with shares in the Brazilian capital market. Considering that the volume of the Brazilian capital market (BM\&FBovespa, 2010) has grown at an annual rate of $27.8 \%$ over the past five years, research on the level of transparency adopted by companies with shares in this market is relevant. We begin with the assumption that information asymmetry is inherent to a contractual relationship (Akerlof, 1970; Spence, 1973; Stiglitz, 2000). This information asymmetry may create market inefficiency (Arrow, 1963), generating adverse consequences for the economy, such as losses in market response to changes in quality and prices (Stiglitz, 2000); inefficient valuation of shares; high cost of capital; and excessive benefits for people who have privileged access to information (Lev, 2001, 2005).

Agency theory would suggest disclosure as a way to reduce agency costs due to, among other things, information asymmetry. On the other hand, the proprietary costs theory indicates that disclosure might increase the company's costs. Consequently, according to these theories, the likelihood that managers voluntarily disclose information depends on certain factors that are characteristic of the company. In the following sections, we present a literature review, formulation of hypotheses, research design, analysis of results, concluding remarks, a list of references and, finally, supplementary information. So, regarding the information assimetry, one question became the propose of this study: What are the factors that can explaining the level of voluntary human capital disclosure in companies with shares in the Brazilian capital market?

\section{Literature review}

Studies such as those by Chow and Wong-Boren (1987), Raffounier (1995), Gray, Meek and Roberts (1995), Meek, Roberts and Gray (1995), Williams (2001) and Macagnan (2005, 2007, 2009) suggest certain factors of a company, such as size, debt, profitability, degree of monopoly and market-to-book ratio, that may motivate managers to voluntarily disclose or withhold information. In other words, managers' decisions to voluntarily reveal or conceal information may be related to the economic characteristics of the company. This concept is 
based on two theories. On the one hand, agency theory implies that the higher the level of disclosure is, the greater the benefits of reducing agency costs may become. On the other hand, the proprietary costs theory opposes it by raising this question: why do companies not fully disclose information to gain the greatest possible benefits? (Verrecchia, 1983; Dye, 1986; Wagenhofer, 1990; Macagnan, 2005, 2007, 2009). According to the proprietary costs theory, the higher the level of company information disclosure is, the higher the costs become (Wagenhofer, 1990). Three types of costs are considered: (1) the cost of preparing and communicating information (Verrecchia, 1983; Elliot \& Jacobson, 1994); (2) costs related to evaluating earnings per share estimates (Verrecchia, 1983, 1990) and (3) the cost of competitive advantage loss due to reactions from competitors drawn from the disclosure of company information (Wagenhofer, 1990).

Understandably, the disclosure of information regarding intangible assets, specifically human capital, has strategic relevance for enterprises because these features, although not always recorded in accounting, represent a competitive business edge in the current economy. Tangible and financial assets are more easily purchased in the market than is a qualified group of professionals. Professionals' qualifications involve costs due to training and time, thus creating opportunities for innovation that will boost a company's competitiveness. Therefore, the competitive edge of a company may be found in the creation and maintenance of its intangible assets. In other words, the increased relevance given to information regarding intangible assets is due to the benefits afforded by such information, such as 'increased productivity, increased profit margins, and, most importantly, innovative products and processes, which are the only means companies can use to escape intense competitive pressure' (Lev, 2004: page 116). Therefore, the disclosure of human capital information may provide benefits to a company, such as those resulting from the reduction of information asymmetry; however, it may also trigger a reaction from competitors, which can result in a loss of competitive advantage. The hypotheses of the current study are presented next.

\section{Hypotheses formulation}

The size of a company is the most commonly analyzed feature in the reviewed studies to explain the level of disclosure in general. Raffournier (1995), Camfferman and Cooke (2002), Watson, Shrives and Marston (2002), Bozzolan, Favotto and Ricceri (2003), Prencipe (2004), Barako, Hancock and Izan (2006), Bronson, Carcello and Raghunandan (2006) and Macagnan (2007) tested the size hypothesis. Large companies have a greater number of contracts between managers and shareholders than small companies and, hence, a greater principalagent problem. A higher level of disclosure might reduce agency costs between managers and shareholders. Another motivation for increased disclosure in a large company is the existence of a more complete information system, which would allow lower costs of obtaining and publishing information compared to those incurred by a small company (Watson et al., 2002). 
It is also understood that a smaller company is more vulnerable to a loss in competitive advantage than a larger company. Thus, we formulate the following hypothesis:

\section{H1: Company size is positively related with the level of human capital disclosure}

Camfferman and Cooke (2002), Watson et al. (2002), Prencipe (2004), Barako et al. (2006) and Macagnan (2007) tested the debt hypothesis. The larger a company's debt is, the more information the company needs to show the market in an attempt to explain the investments and justify its degree of debt. Companies with larger debts are significantly more likely to voluntarily disclose information (Brammer \& Pavelin, 2006). Disclosure represents a means through which managers may expose the reasons for debt. Therefore, we formulate the following hypothesis:

H2: The level of debt is positively related to the level of human capital disclosure

Watson et al. (2002), Camfferman and Cooke (2002), Salotti and Yamamoto (2008) and Macagnan (2007) tested the profitability hypothesis. When a company does not reach the expected profitability, managers may provide more information to justify to shareholders the reasons for the low profitability achieved (Wagenhofer, 1990). This disclosure, besides being used as a justification for poor performance, may signal future initiatives undertaken to reverse the situation. Therefore, human capital disclosure could serve to reassure shareholders. Thus, we formulate the following hypothesis:

\section{H3: Profitability is negatively related to the level of human capital disclosure}

Owusu-Ansah (1998), Barako et al. (2006) and Al-Mutawwa and Hewaidy (2010) tested the liquidity hypothesis. A liquidity indicator allows for the determination of a company's ability to meet its financial obligations in the short term. Wallace, Naser and Mora (1994) found evidence that managers of companies with low liquidity are motivated to increase disclosure in an attempt to show its shareholders that they are aware of their lower ability to honor financial obligations in the short term. Therefore, we formulate the following hypothesis:

H4: The degree of liquidity is negatively related to the level of human capital disclosure

Inchausti (1997), Watson et al. (2002) and Macagnan (2007) tested the paid-dividends hypothesis. When the company pays dividends to shareholders, it is demonstrating that it is profitable and that it is prioritizing its own interests. The dividend policy could be used to reduce agency costs because the regular payment of dividends helps to maintain a company's structure and stability, ruling out the transfer of wealth from owners to creditors (Inchausti, 1997). Thus, the lower the payment of dividends to shareholders is, the greater the level of 
disclosure on investment in human resources becomes, which is justified by the possibility of increasing future earnings. Hence, we propose the following hypothesis:

H5: The amount of dividends paid per share is negatively related to the level of human capital disclosure

McNally, Eng and Hasseldine (1982), Prencipe (2004) and Bronson et al. (2006) tested the growth hypothesis. The number of contracts between managers and shareholders increases with the growth of a company, emphasizing the problem of information asymmetry. Thus, disclosing more information could reduce this problem. However, human capital disclosure in emerging companies could lead to a loss of competitive advantage given the competitors' reactions, which could explain why the fastest growing companies disclose less information. "Information asymmetry is, undoubtedly, a key component, which constitutes a competitive advantage" (Spence, 2006: page 2). Consequently, for growing businesses, the disclosure of information regarding intangible assets could mean a loss of competitive advantage. Therefore, we formulate the following hypothesis:

H6: A company's growth is negatively related to the level of human capital disclosure

Macagnan (2007) and Salotti and Yamamoto (2008) tested the stock volatility hypothesis. Investors spend their funds in shares of companies when their expected return is high enough to offset the risk of the asset (Ross, Westerfield and Jaffe, 2008). Thus, for companies with higher volatility in the value of their shares, human capital disclosure could be adjusted to allow for the further evaluation of its assets, which, consequently, could reduce the volatility of company stock. Thus, we formulate the following hypothesis:

\section{H7: The volatility of company stock is positively related to level of human capital disclosure}

Macagnan (2007) and Salotti and Yamamoto (2008) tested the floating capital hypothesis. When stock ownership is too diffused and split, the shareholder does not have effective management control (Ross, Westerfield and Jaffe, 2008). Therefore, when a company has a high percentage of floating capital, its shares are dispersed throughout the market and held by many investors. For companies with more floating capital, human capital disclosure could reduce the problems related to information asymmetry and agency costs. Thus, we formulate the following hypothesis:

H8: Floating capital is positively related to the level of human capital disclosure

Macagnan (2007) tested the market-to-book ratio hypothesis. The difference between the market value of a company and its book value might be explained by the shareholders' expectations regarding potential future benefits from the company. In an attempt to sustain 
this favorable assessment of the company, managers could increase human capital disclosure to justify that such a difference in pricing stems from not accounting for human capital. Therefore, we formulate the following hypothesis:

H9: The market-to-book ratio is positively related to the level of human capital disclosure

Abdullah and Ismail (2008) tested the efficiency hypothesis. The more efficient an organization is in using its assets and raising funds, the greater the manager's motivation becomes for human capital disclosure to legitimize his or her management behavior and justify his or her pay. Thus, we formulate the following hypothesis:

\section{H10: The efficiency of a company is positively related to the level of human capital disclosure}

The Brazilian Securities and Exchange Commission (Comissão de Valores Mobiliários, CVM) is the federal agency responsible for allowing public companies to issue securities through registration. Companies are required to periodically report certain information to the CVM, which allows investors to better evaluate the initiatives of companies. The CVM stipulates a minimum level of disclosure by a company. However, companies that have been registered with the CVM for a longer time, and thus possess greater maturity and strength in capital markets, can reveal more information than companies with a more recent registration to reduce agency costs. Thus, we formulate the following hypothesis:

H11: The time of registration with the CVM is positively related to the level of human capital disclosure

Table 1 shows the eleven hypotheses of this study and their relation to the expected level of voluntary human capital disclosure of companies in the sample.

\begin{tabular}{|c|c|c|}
\hline Order & Hypotheses & Expected Relation \\
\hline 1 & Size & + \\
\hline 2 & Debt & - \\
\hline 3 & Profitability & - \\
\hline 4 & Liquidity & - \\
\hline 5 & Dividends & + \\
\hline 6 & Growth & + \\
\hline 7 & Volatility & + \\
\hline 8 & Floating Capital & + \\
\hline 9 & Market-to-book ratio & + \\
\hline 10 & Efficiency & + \\
\hline 11 & Time of Registration with CVM & + \\
\hline
\end{tabular}

Table 1. Hypotheses and expected relation

The methodological procedures of this research are detailed below. 


\section{Research design}

To identify the relationship between explanatory factors and the level of disclosure, and after reviewing the empirical literature, we created a model of analysis represented by the following formula (1):

$$
\begin{aligned}
& D L_{i t}=\beta_{0}+\beta_{1} T_{o t}{ }_{i t}+\beta_{2} S_{a l} l_{i t}+\beta_{3} D_{e b t_{i t}}+\beta_{4} R_{0 o a_{i t}}+\beta_{5} G_{-} R o a_{i t}+\beta_{6} N W C_{i t}+\beta_{7} D_{i V_{i t}}+ \\
& B_{8} A s S \_G_{i t}+B_{9} G \_S a l_{i t}+\beta_{10} V_{o l}+\beta_{11} G_{-} F_{l o}+\beta_{12} S V \_B V_{i t}+\beta_{13} T_{i m}+\varepsilon_{i t}
\end{aligned}
$$

where

$D L=$ level of human capital disclosure of company " $i$ " in year " $t$ ";

$B_{i}=$ parameters to be estimated;

Tot $_{\text {it }}=$ total assets of company " $i$ " in year " $t$ ";

$S a l_{i t}=$ sales of company " $i$ " in year " $t$ ";

Debt $t_{i t}=$ debt of company " $i$ " in year " $t$ ";

$R_{0 a} a_{\text {it }}=$ return on assets of company " $i$ " in year " $t$ ";

$G_{-} R o a_{i t}=$ ROA growth of company " $i$ " in year " $t$ ";

$N W C_{i t}=$ net working capital of company " $i$ " in year " $t$ ";

$\operatorname{Div}_{i t}=$ earnings per share of company " $i$ " in year " $t$ ";

Ass_ $G_{i t}=$ assets growth of company " $i$ " in year " $t$ ";

$G_{-} S a l_{i t}=$ sales growth of company " $i$ " in year " $t$ ";

$V_{\text {ol }}$ = share volatility of company " $i$ " in year " $t$ ";

$C_{-} F o_{\text {it }}=$ floating capital of company " $i$ " in year " $t$ ";

$S V \_B V_{i t}=$ share price divided by its book value of company " $i$ " in year " $t$ ";

$\operatorname{Tim}_{i t}=$ time of registration with CVM of company " $i$ " in year " $t$ ";

$\varepsilon_{i t}=$ random error expressing the effect of omitted variables on company " $i$ " in year " $t$ ";

$i=$ companies, from 1 to 29 ;

$t=$ years, from 2005 to 2009 .

It is worth clarifying some aspects of measuring the level of Human Capital Disclosure (DL). Disclosure is recognized as an abstract concept that cannot be measured directly. Empirical research studies on the issue use indexes constructed from indicators that better represent the information to measure the disclosure. The index is a numerical result that represents the amount of information disclosed by a company. The quality of the information and whether it is fraudulent or incorrect are not analyzed, even though quantity is sometimes associated with quality. One might question the subjectivity of the indicators and indexes; however, a different method that would enable the use of statistical techniques in the analysis of factors that explain the level of disclosure has not yet been developed. 
In this study, we used the disclosure index, comprised of 30 indicators, used in the research by Macagnan (2005) as Appendix A, which represents information regarding human capital. This index includes information about intangible assets related to the skills and technical abilities of company employees (Macagnan 2005, 2007, 2009). The level of disclosure can be obtained by the following formula (2):

$$
I_{j}=\frac{\sum_{i=1}^{n} x_{i j}}{n_{j}}
$$

where $n_{j}$ is the number of human resource disclosure indicators expected for each company, $j$ is the company, $i$ is the indicator and $X_{i j}$ assumes a value of 1 if the $i$ indicator is revealed and 0 otherwise. Hence, the level of disclosure is the sum of the scores for each indicator (Khanna, Palepu \& Srinivasan 2004). With regard to weighting, this study considered all indicators to be equivalent and did not assign different weights.

The source of data used to analyze the level of human capital disclosure was the annual report. The choice of the annual report for review followed the trend of most studies on disclosure. In addition to representing an official document of the company, the report is a legally recognized document that can be used in litigation cases.

The explanatory variables representing the hypotheses listed in Table 2 were defined from the reviewed literature.

\begin{tabular}{|c|c|c|}
\hline Hypotheses & Variables & Formulas \\
\hline \multirow{2}{*}{ 1. Size } & Total Assets & Total Assets Value \\
\hline & Total Sales & Total Sales Value \\
\hline 2. Debt & Debt & $\begin{array}{l}\text { [(Total Liabilities - Net Equity) / Total } \\
\text { Assets }] \times 100\end{array}$ \\
\hline \multirow{2}{*}{ 3. Profitability } & Return On Assets (ROA) & (Net Profit / Total Assets) $\times 100$ \\
\hline & ROA Growth & {$\left[\left(R_{0} A_{t} / R^{\prime} A_{t-1}\right)-1\right] \times 100$} \\
\hline 4. Liquidity & Net Current Capital & Current Assets - Current Liabilities \\
\hline 5. Dividends & Earnings per share & Earnings per common share \\
\hline \multirow{2}{*}{ 6. Growth } & Assets Growth & {$\left[\left(\right.\right.$ Total Assetst $/$ Total Assets $\left.\left.\mathrm{t}_{-1}\right)-1\right] \times 100$} \\
\hline & Sales Growth & {$\left[\left(\right.\right.$ Sales $_{\mathrm{t}} /$ Sales $\left.\left._{\mathrm{t}-1}\right)-1\right] \times 100$} \\
\hline 7. Volatility & Share Volatility & $($ Common Share Volatility $) \times 100$ \\
\hline 8. Floating Capital & Floating Capital & \% Floating Capital \\
\hline 9. Market-to-book ratio & Share Value/Book Value & (Share price / Share Book Value) $\times 100$ \\
\hline 10. Efficiency & Working Assets & (Sales / Total Assets) $\times 100$ \\
\hline 11. Time of Registration with CVM & Time of Registration with CVM & 2009 - Year of Registration with CVM \\
\hline
\end{tabular}

Table 2. Hypotheses, variables and respective formulas 
For the explanatory variables, the data sources used here include the information available on the website of the stock exchange BM\&FBovespa and the Economática database. This study initially included 531 companies listed in the Brazilian Stock Exchange. However, 58 companies were excluded because their web pages on the Internet were under construction or had technical problems, which prevented access to the publication of their annual reports; 440 companies were excluded because they did not provide one or more annual reports on their web pages; 2 companies were excluded because they had not been listed since 2005; and 2 companies were excluded because they were incorporated into other companies in the period 2005-2009. Therefore, the final number of companies studied was 29, from 2005 to 2009 (five years), which resulted in a final sample of 145 annual reports reviewed. The annual reports were analyzed using content analysis, in which human resources disclosures were found. The software EViews was used to process the data and obtain the statistical results of empirical investigation.

\section{The empirical investigation}

The analysis of factors explaining the level of voluntary human capital disclosure, through the technique of multiple linear regression using panel data, was preceded by three considerations: (i) descriptive analysis of the level of disclosure, (ii) correlation analysis between the explanatory variables, and (iii) analysis of fixed or random effect on panel data.

The descriptive analysis of the level of disclosure of the sample indicated that the basic industry sector is the most representative sample, with a participation percentage of $44.8 \%$. It is $29.9 \%$ more representative than the trade, services and transport sector and $116.4 \%$ more representative than the manufacturing sector. Regarding trade, transport and services and manufacturing sectors, the former is $66.7 \%$ more representative than the latter.

The correlation analysis between the explanatory variables, the results of which are presented in Table 3, only allowed for the selection variables that were not significantly correlated. Thus, the model only included variables with correlations inferior to 0.59 . Therefore, among the 11 tested cases, there is no significant correlation between the explanatory variables that could affect the consistency of the results.

The analysis of fixed or random effects in the panel data identified, which effect would be most appropriate for the model. Through the Hausman test (Wooldridge, 2010), we found that one or more of the variables used were correlated with the unobserved effect. For this reason, the regression was performed with the fixed effect. Below, we analyze the model results. 


\begin{tabular}{|c|c|c|c|c|c|c|c|c|c|c|c|c|c|c|}
\hline & 1 & 2 & 3 & 4 & 5 & 6 & 7 & 8 & 9 & 10 & 11 & 12 & 13 & 14 \\
\hline 1. Ass & 1.00 & & & & & & & & & & & & & \\
\hline 2. Sal & 0.48 & 1.00 & & & & & & & & & & & & \\
\hline 3. Debt & 0.47 & 0.01 & 1.00 & & & & & & & & & & & \\
\hline 4. Roa & -0.27 & -0.02 & -0.30 & 1.00 & & & & & & & & & & \\
\hline 5. G_Roa & -0.01 & -0.01 & -0.11 & 0.30 & 1.00 & & & & & & & & & \\
\hline 6. NWC & 0.28 & 0.07 & 0.12 & -0.08 & -0.01 & 1.00 & & & & & & & & \\
\hline 7. Div & -0.03 & 0.09 & 0.08 & 0.21 & 0.00 & -0.10 & 1.00 & & & & & & & \\
\hline 8. G_Ass & 0.20 & 0.05 & 0.13 & -0.12 & -0.14 & 0.14 & -0.12 & 1.00 & & & & & & \\
\hline 9. G_Sal & 0.00 & -0.04 & 0.01 & 0.08 & 0.32 & -0.01 & -0.07 & 0.35 & 1.00 & & & & & \\
\hline 10. Vol & 0.10 & 0.28 & -0.08 & -0.02 & 0.00 & -0.02 & 0.54 & -0.03 & -0.06 & 1.00 & & & & \\
\hline 11. C_Flo & 0.29 & 0.29 & -0.08 & -0.01 & -0.12 & 0.41 & -0.21 & 0.29 & 0.08 & -0.04 & 1.00 & & & \\
\hline 12. SV_BV & -0.03 & -0.04 & 0.12 & 0.51 & -0.04 & 0.01 & 0.20 & 0.00 & 0.08 & 0.02 & 0.03 & 1.00 & & \\
\hline 13. C_Ass & -0.51 & -0.19 & -0.40 & 0.30 & 0.10 & -0.17 & -0.05 & -0.10 & 0.11 & -0.02 & -0.10 & 0.00 & 1.00 & \\
\hline 14. Tim & 0.44 & 0.30 & -0.06 & -0.12 & 0.07 & 0.15 & -0.31 & -0.02 & -0.14 & -0.04 & 0.24 & -0.31 & -0.19 & 1.00 \\
\hline
\end{tabular}

Table 3. Correlation matrix of explanatory variables

Table 4 presents the results of statistical regression. Given the adjusted R-squared value, one can infer that $66.3 \%$ of the variations in the level of disclosure can be explained by variations in the explanatory variables. As a result, one cannot reject six variables as explaining the level of voluntary human capital disclosure, which showed significance levels of $1 \%$ and $5 \%$.

\begin{tabular}{|c|c|c|c|c|}
\hline \multicolumn{5}{|c|}{ Dependent Variable: DL } \\
\hline \multicolumn{4}{|c|}{ Method: Panel data by Ordinary Least Squares } & Effect: Fixed \\
\hline \multicolumn{2}{|c|}{ Sample: 29 Companies } & \multirow{2}{*}{$\begin{array}{r}\text { Period: } 2005-2009 \\
\text { Standard Error }\end{array}$} & \multicolumn{2}{|c|}{ Total Observations: 145} \\
\hline Variable & Coefficient & & t Statistics & Probability \\
\hline Ass & -0.047931 & 0.008005 & -5.987543 & $0.0000^{*}$ \\
\hline Sal & 0.218208 & 0.050288 & 4.339136 & $0.0000 *$ \\
\hline Debt & 0.245744 & 0.099985 & 2.457819 & $0.0155^{* *}$ \\
\hline G_Ass & -0.096876 & 0.022859 & -4.238010 & $0.0000 *$ \\
\hline G_Sal & -0.091520 & 0.044878 & -2.039315 & $0.0438 * *$ \\
\hline Tim & 1.413947 & 0.445203 & 3.175961 & $0.0019 *$ \\
\hline Constant & 5.321690 & 12.28038 & 0.433349 & 0.6656 \\
\hline R-square & 0.742591 & F Statistics & \multicolumn{2}{|r|}{9.333385} \\
\hline R-square adjusted & 0.663028 & Prob (F Statistics) & \multicolumn{2}{|r|}{0.000000} \\
\hline Prob (White Test) & 0.996147 & Durbin-Watson & \multicolumn{2}{|r|}{1.893186} \\
\hline
\end{tabular}

Table 4. Results

According to the results shown in Table 4, the greater the sales, debt and time of registration with the CVM variables are, the higher the level of voluntary human capital disclosure will be. 
However, the greater the total assets, asset growth and sales growth variables are, the lesser the level of voluntary human capital disclosure will be.

The size hypothesis, represented by the variable total assets, cannot be rejected as explaining voluntary human capital disclosure due to its significance level of $1 \%$. Notwithstanding, it did show a negative relationship with disclosure, contrary to the results of all of the reviewed studies that did not reject the size hypothesis. This same hypothesis, represented by the variable sales, cannot be rejected; its significance level was $1 \%$. It did show a positive relationship with disclosure, confirming the results by Cooke $(1989,1996)$, Wallace et al. (1994), Meek et al. (1995), Raffournier (1995), Inchausti (1997), Bozzolan et al. (2003), Prencipe (2004) and Macagnan (2007). The results of the size hypothesis, represented by the sales variable, can be explained by agency theory because the larger a company is, the greater the number of contracts the company will have and, consequently, the greater the information asymmetry between managers and shareholders will be. This effect may generate a greater demand for disclosure in the quest to reduce agency costs.

The debt hypothesis cannot be rejected; its significance level was $5 \%$, presenting a positive relationship with the disclosure. This result confirms the studies by Malone, Frie and Jones (1993), Hossain, Perera and Rahman (1995), Mitchell, Chia and Loh (1995), Cooke (1996), Richardson and Welker (2001), Williams (2001), Bujaki and McConomy (2002), Camfferman and Cooke (2002), Ferguson, Lam and Lee (2002), Prencipe (2004), Barako et al. (2006) and Macagnan (2007). The outcome of the debt hypothesis can be explained by agency theory because the management would disclose more information to reduce information asymmetry; that is, a greater level of disclosure could justify a high company debt because it would be due to investments in human capital.

The growth hypothesis, represented by the total assets and sales growth variables, cannot be rejected; the variables exhibited significance levels of $1 \%$ and $5 \%$, respectively, and are negatively correlated with the level of disclosure. This result confirms the results from the studies of Bronson et al (2006). The larger company growth is, the lower the level of human capital disclosure will be. This result supports the proprietary costs theory because more information increases the chances of a company suffering a loss in competitive advantage.

The hypothesis regarding the time of registration with the CVM, which was not compared to any study reviewed, cannot be rejected as explaining the level of human capital disclosure. At a significance level of $1 \%$, it shows a positive relationship with disclosure. This result provides evidence to support agency theory because managers of companies that are registered with the CVM for a longer period of time may have disclosed more information to the market in an attempt to improve the evaluation of shares. 
The profitability, liquidity, floating capital and market-to-book ratio hypotheses were statistically rejected. We found no significant relationship between the variables representing these hypotheses and the level of voluntary human capital disclosure.

\section{Conclusions}

The aim of this study was to analyze the factors explaining the level of voluntary human capital disclosure by companies listed on the BM\&FBovespa during the period of 2005-2009. Faced with the problem of information asymmetry, human capital disclosure may be a way to reduce the level of information asymmetry between managers and shareholders. The study was based on the fact that companies have different levels of disclosure and, therefore, on the motivations of management to voluntarily reveal more or less information.

To analyze the results obtained, we used the assumptions of two theories: Agency theory, which states that disclosure can reduce agency costs, and the proprietary costs theory, which notes that disclosure may create costs for the company. Given the strategic importance of information on intangible assets, the analysis focused on human capital disclosure.

The main results of this study indicate that the following should not be rejected: size, debt, growth and time of registration with the CVM hypotheses, with significance levels of $1 \%$ and $5 \%$, as explaining the level of human capital disclosure. However, the profitability, liquidity, dividend per share, floating capital, market-to-book ratio, stock volatility and efficiency hypotheses were rejected. An important contribution of this research is the formulation and non-repudiation of the time of registration with the CVM hypothesis as a factor that explains the level of human capital disclosure because none of the revised studies have tested this hypothesis.

Regarding the reviewed theories, it appears that none of them can fully explain the management motivation for voluntary human capital disclosure. However, with respect to the model used in this study, we can conclude the following:

- The hypotheses of size (sales), debt and time of registration with the CVM are explained based on the assumptions of agency theory. The positive relationship indicates that managers' motivation for voluntary disclosure is justified by the reduction in information asymmetry between managers and shareholders;

- The hypotheses of size (total assets) and growth (total assets and sales) are explained based on the assumptions of the proprietary costs theory because the costs of competitive advantage losses in human capital disclosure outweigh the benefits of reducing information asymmetry. 
The study was limited to examining only the presence or absence of voluntary human capital disclosure in annual reports. Therefore, the evaluation of these resources was not within the scope of this research; moreover, intangible liabilities were not covered.

For future studies, we recommend the replication of this study in a sample of companies from another country to conduct a comparative analysis of results, which would enhance the understanding of the factors explaining the level of voluntary human capital disclosure. Another possibility for research could be analysing the another media of comunication used by the companies, like the information disclosure in the internet via websites.

\section{References}

ABDULLAH, A.B.; ISMAIL, K.N.I.K. (2008). Disclosure of Voluntary Accounting Ratios by Malaysian Listed Companies. Journal of Financial Reporting \& Accounting, 6(2): 1-20. http://dx.doi.org/10.1108/19852510880000632

AKERLOF, G.A. (1970). The Market for "Lemons": Quality Uncertainty and the Market Mechanism. The Quarterly Journal of Economics, 84(3): 488-500. http://dx.doi.org/10.2307/1879431

AL-MUTAWAA, A.; HEWAIDY, A.M. (2010). Disclosure Level and Compliance With IRFSs: An Empirical Investigation of Kuwaiti Companies. International Business \& Economics Research Journal, 9(5): 33-49.

ARROW, K. (1963). Uncertainty and the welfare economics of medical care. The American Economic Review, V(LIII): 1-9.

BARAKO, D.G.; HANCOCK, P.; IZAN, H.Y. (2006). Factors Influencing Voluntary Corporate Disclosure by Kenyan Companies. Corporate Governance: An International Review, 14(2): 107-125. http://dx.doi.org/10.1111/j.1467-8683.2006.00491.x

BM\&FBOVESPA (2010). Relatorio Anual. Available at: http://www.bmfbovespa.com.br/ptbr/abmfbovespa/download/BMFVOVESPA-Relatorio-Anual-2010.pdf.

BOZZOLAN, S.; FAVOTTO, F.; RICCERI, F. (2003). Italian annual intellectual capital disclosure: An empirical analysis. Journal of Intellectual Capital, 4(4): 543-558. http://dx.doi.org/10.1108/14691930310504554

BRAMMER, S.; PAVELIN, S. (2006). Voluntary Environmental Disclosures by Large UK Companies. Journal of Business Finance \& Accounting, (33): 1168-1188. http://dx.doi.org/10.1111/j.1468-5957.2006.00598.x

BRONSON, S.N.; CARCELLO, J.V.; RAGHUNANDAN, K. (2006). Firm Characteristics and Voluntary Management Reports on Internal Control. Auditing: A Journal of Practice \& Theory, 25(2): 25-39. 
BUJAKI, M.; MCCONOMY, B.J. (2002). Corporate Governance: Factors Influencing Voluntary Disclosure by Publicly Traded Canadian Firms. Canadian Accounting Perspectives, 1(2): 105-139. http://dx.doi.org/10.1506/9FN9-ECC9-7GL7-25NT

CAMFFERMAN, K.; COOKE, T.E. (2002). An Analysis of Disclosure in the Annual Reports of U.K. and Dutch Companies. Journal of International Accounting Research, (1): 3-30.

CHOW, C.W.; WONG-BOREN, A. (1987). Voluntary Financial Disclosure by Mexican Corporations. The Accounting Review, LXII(3): 533-541.

COOKE, T.E. (1989). Disclosure in the Corporate Annual Reports of Swedish Companies. Accounting and Business Research, 113-124. http://dx.doi.org/10.1080/00014788.1989.9728841

COOKE, T.E. (1996). The Influence of the Keiretsu on Japanese Corporate Disclosure. Journal of International Financial Management and Accounting, 7(3): 191-214. http://dx.doi.org/10.1111/j.1467-646X.1996.tb00071.x

DYE, R.A. (1986). Proprietary and Nonproprietary Disclosures. Journal of Business, 59(2): 331-366. http://dx.doi.org/10.1086/296331

ELLIOTT, R.K.; JACOBSON, P.D. (1994). Cost and Benefits of Business Information Disclosure. Accounting Horizons, 8(4): 80-96.

FERGUSON, M.J.; LAM, K.C.K.; LEE, G.M. (2002). Voluntary Disclosure by State-owned Enterprises Listed on the Stock Exchange of Hong Kong. Journal of International Financial Management \& Accounting, 13(2): 125-152. http://dx.doi.org/10.1111/1467-646X.00081

GRAY, S.J.; MEEK, G.K.; ROBERTS, C.B. (1995). International Capital Market Pressures and Voluntary Annual Report Disclosure by U.S. and U.K. Multinationals. Journal of International Financial Management and Accounting, 6(1): 43-68. http://dx.doi.org/10.1111/j.1467646X.1995.tb00049.x

HOSSAIN, M.; PERERA, M.H.B.; RAHMAN, A.R. (1995). Voluntary Disclosure in the Annual Reports of New Zealand Companies. Journal of International Financial Management and Accounting, 6(1): 69-87. http://dx.doi.org/10.1111/j.1467-646X.1995.tb00050.x

INCHAUSTI, B.G. (1997). The influence of company characteristics and accounting regulation on information disclosure by Spanish firms. The European Accounting Review, 6(1): 45-68. http://dx.doi.org/10.1080/096381897336863

KHANNA, T.; PALEPU, K.G.; SRINIVASAN, S. (2004). Disclosure Practices of Foreign Companies Interacting with U.S. Markets. Journal of Accounting Research, 42(2): 475-508. http://dx.doi.org/10.1111/j.1475-679x.2004.00146.x

LEV. B. (2001). Intangible - Management, Measurement and Reporting, Washington: Brookings Institution Press. http://dx.doi.org/10.1016/B0-12-369398-5/00471-0 
LEV, B. (2004). Sharpening the Intangibles Edge. Harvard Business Review, 82(6): 109-116.

LEV, B. (2005). Intangible Assets: Concepts and Measurements. Enciclopedia of Social Measurement, 2: 299-305.

MACAGNAN, C.B. (2005). Factores explicativos de la revelación de información de activos intangibles de empresas que cotizan en España. Trabajo de investigación, Universitat Autònoma de Barcelona.

MACAGNAN, C.B. (2007). Condicionantes e implicación de revelar activos intangibles. Ph.D. dissertation, Universitat Autònoma de Barcelona.

MACAGNAN, C.B. (2009). Evidenciação voluntária: fatores explicativos da extensão da informação sobre recursos intangíveis. Journal of Contabilidade \& Finanças, 20(50): 46-61. http://dx.doi.org/10.1590/S1519-70772009000200004

MALONE, D.; FRIES, C.; JONES, T. (1993). An Empirical Investigation of the Extent of Corporate Financial Disclosure in the Oil and Gas Industry. Journal of Accounting, Auditing \& Finance, 8(3): 249-275.

MCNALLY, G.M.; ENG, L.H.; HASSELDINE, C.R. (1982). Corporate Financial Reporting in New Zealand: An Analysis of User Preferences, Corporate Characteristics and Disclosure Practices for Discretionary Information. Accounting and Business Research, 49: 11-20.

MEEK, G.K.; ROBERTS, C.B.; GRAY, S.J. (1995). Factors Influencing Voluntary Annual Report Disclosures by U.S., U.K. and Continental European Multinational Corporations. Journal of International Business Studies, 26(3): 555-572. http://dx.doi.org/10.1057/palgrave.jibs.8490186

MITCHELL, J.D.; CHIA, C.W.L.; LOH, A.S. (1995). Voluntary Disclosure of Segment Information: Further Australian Evidence. Accounting and Finance, 35(2): 1-16. http://dx.doi.org/10.1111/j.1467-629X.1995.tb00283.x

OWUSU-ANSAH, S. (1998).The Impact of Corporate Attributes on the Extent of Mandatory Disclosure and Reporting by Listed Companies in Zimbabwe. The International Journal of Accounting, 33(5): 605-631. http://dx.doi.org/10.1016/S0020-7063(98)90015-2

PRENCIPE, A. (2004). Proprietary Costs and Determinants of Voluntary Segment Disclosure: Evidence from Italian Companies. European Accounting Review, 13(2): 319-340. http://dx.doi.org/10.1080/0963818042000204742

RAFFOURNIER, B. (1995). The determinants of voluntary financial disclosure by Swiss listed companies. The European Accounting Review, 4(2): 261-280. http://dx.doi.org/10.1080/09638189500000016 
RICHARDSON, A.J.; WELKER, M. (2001). Social disclosure, financial disclosure and the cost of equity capital. Accounting, Organizations and Society, (26): 597-616. http://dx.doi.org/10.1016/S0361-3682(01)00025-3

ROSS, S.; WESTERFIELD, R.W.; JAFFE, J.F. (2008). Administração Financeira, São Paulo: Atlas.

SALOTTI, B.M.; YAMAMOTO, M.M. (2008). Divulgação Voluntária da Demonstração dos Fluxos de Caixa no Mercado de Capitais Brasileiro. Revista de Contabilidade e Finanças - USP, 19(48): 37-49.

SPENCE, M. (1973). Job Market Signaling. The Quarterly Journal of Economics, 87(3): 355-374. http://dx.doi.org/10.2307/1882010

SPENCE, M. (2006). Entrevista Michael Spence: Assimetria de informação é parte da inovação, ed. J. Nascimento Rodrigues. Available at: http://www.janelaweb.com/digitais/spence.html.

STIGLITZ, J.E. (2000). The Contributions of the Economics of Information to Twentieth Century Economics. The Quarterly Journal of Economics, 115(4): 1441-1478. http://dx.doi.org/10.1162/003355300555015

VERRECCHIA, R.E. (1983). Discretionary Disclosure. Journal of Accounting and Economics, (5): 179-194. http://dx.doi.org/10.1016/0165-4101(83)90011-3

VERRECCHIA, R.E. (1990). Endogenous Proprietary Costs Through Firm Interdependence. Journal of Accounting and Economics, (12): 245-250. http://dx.doi.org/10.1016/01654101(90)90049-A

WAGENHOFER, A. (1990). Voluntary Disclosure With a Strategic Opponent. Journal of Accounting and Economics, (12): 341-363. http://dx.doi.org/10.1016/0165-4101(90)90020-5

WALLACE, R.S.O.; NASER, K.; MORA, A. (1994). The Relationship Between the Comprehensiveness of Corporate Annual Reports and Firm Characteristics in Spain. Accounting and Business Research, 25(97): http://dx.doi.org/10.1080/00014788.1994.9729927

WATSON, A.; SHRIVES, P.; MARSTON, C. (2002). Voluntary Disclosure of Accounting Ratios in the UK. British Accounting Review, (34): 289-313. http://dx.doi.org/10.1006/bare.2002.0213

WILLIAMS, S.M. (2001). Is intellectual capital performance and disclosure practices related? Journal of Intellectual Capital, 2(3): 192-203. http://dx.doi.org/10.1108/14691930110399932

WOOLDRIDGE, J.M. (2010). Indrodução à Econometria - Uma Abordagem Moderna, São Paulo: Cengage Learning. 


\section{Appendix A. Indicators representative of information regarding human capital establishing the disclosure index}

\section{TEMS}

\section{HUMAN CAPITAL}

Number of employees

Progression in the number of employees in recent years

Number of terminations

New Hires

Absence or lack of staff

External rotation of staff

Internal rotation of staff

Employees scaled by seniority

Employees scaled by job description

Employees scaled by age

Employees scaled by education

Employees scaled by gender

Employees scaled by region

Description of training activities undertaken

Training activities hours

Training expenses

Employees with access to training

Hiring policy/recruitment

Pay policy and system

Career plan

Incentives program

Company benefits and social programs

Health and safety policy

Information on collective agreements

Measures of employee satisfaction

Production or productivity per employee

Revenue per employee

Work experience of chief executives in other companies

Education of chief executives

New hiring of executives

Source: Macagnan (2005)

(c) Intangible Capital, 2013 (www.intangiblecapital.org)

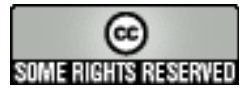

El artículo está con Reconocimiento-NoComercial 3.0 de Creative Commons. Puede copiarlo, distribuirlo y comunicarlo públicamente siempre que cite a su autor y a Intangible Capital. No lo utilice para fines comerciales. La licencia completa se puede consultar en http://creativecommons.org/licenses/by-nc/3.0/es/ 